\title{
Optimization of Nitrogen Content for Improved Cry1Ac Expression Level in Bt Cotton
}

\author{
R. Peardon ${ }^{1}$, M. Devasahayam ${ }^{2}$, A. Maxton ${ }^{1}$ and S.A. Masih $^{1 *}$ \\ ${ }^{1}$ Molecular and Cellular Engineering, Sam Higginbottom University of Agriculture, \\ Technology and Sciences, Prayagraj, India-211007 \\ ${ }^{2}$ Centre for Transgenic Technology, Sam Higginbottom University of Agriculture, Technology \\ and Sciences, Prayagraj, India-211007 \\ *Corresponding author
}

\section{A B S T R A C T}

\section{Keywords \\ $B t$ cotton (Bollgard- II), Nitrogen, $n B t$ cotton, Cry1Ac expression \\ Article Info \\ Accepted: \\ 10 April 2019 \\ Available Online: \\ 10 May 2019}

Bacillus thuringiensis is produced crystalline proteins, these proteins were used in transgenic cotton to control insect pest. During present study, two trials were with 09 treatments plots of $\mathrm{Bt}$ cotton plants viz., 7, 14 and $21 \mathrm{gm} / \mathrm{m} . \mathrm{sq}$. (T1, T2 amd T3) of nitrogen with one row combination of $n B t$ cotton plants while T4, T5, T6 were having two rows combination of $n B t$ cotton plants with same nitrogen treatment as in above mentioned plots whereas T7, T8 and T9 were only treatment with different concentration of nitrogen and there was no rows of $n B t$ cotton plants around the plots were conducted. During this, CrylAc protein expression level was analyzed. The results were compared in two ways, one between the plots having same $n B t$ rows but with different nitrogen concentration in the soil and another among overall plots. The expression level was high on initial days (30th day) that decrease gradually. Overall, T6 treatment showed highest Crylac expression i.e., $6.443(\mu \mathrm{g} / \mathrm{gm})$ whereas lowest reported expression was in plot T7. These results show that the nitrogen content and different rows combination of the $n B t$ expressed a prominent effect over the expression of Cry 1 Ac protein.

\section{Introduction}

Pesticides are the main cause of loss to the farmers, every year hectares of crop get spoiled due to pesticides. To reduce that heavy loss implementation of chemicals as pesticides to control pest is usual in agriculture. There are many pesticides reported which are of both chemical and biological nature used in most of the countries to reduce crop losses. This issue is prominent in developing countries there farmers are most affected for agriculture crop loss due to high occurrence of pests. In India, estimated yearly agriculture production losses because of pests are as high as US\$ 42.66 million. Whereas chemical pesticides are well known for their success rate, but their effect on soil and environment, footprints of residue in food products are subject of concern (Subhash et al., 2017). To overcome this problem mother nature has shown a way to treat our crops with toxins which are already present in our ecosystem, which is Cry protein. Extracted 
Cry toxin proteins from the bacterium Bacillus thuringiensis (Bt) are used in sprays or produced by transgenic crops for pest control which is environmentally friendly and non hazardous for humans. The enormous varieties of Cry proteins present shared structural three-domain group, which has a similar mode of action. The Cry1Ac toxin is one of the most active $\mathrm{Bt}$ toxins against the larvae of Lepidoptera.

The steps involved in the mode of action of Cry1Ac and other three-domain Bt toxins have been rigorously studied (Dohare and Tank, 2014). After ingestion, the Cry1Ac toxin is processed in the midgut fluids to an active core that identifies binding sites in proteins in the midgut brush border epithelium. This binding is conducive to further processing of the toxin and formation of an oligomer, which inserts in the membrane of midgut cells to form a pore through the insertion of amphipathic alpha helices in domain I. The toxin pore leads to osmotic cell death, collapsing of the midgut epithelial barrier, and invasion by resident midgut bacteria of the hemocoel to cause septicemia and the death of the insect (Mushtaq et al., 2018).

Cotton (Gossypium hirsutum) is a chief fiber crop which is grown largely in many parts of the globe. Instead of only giving exceptionally valuable fiber, cotton seed are utilized as a source of edible oil and seed cake, which is used as animal feed. In 2014, $\sim 37$ million hectares of land was sown with cotton worldwide, mostly under rain fed and dryland conditions. In India alone, the crop was grown in $\sim 12.25$ million hectares of land (James, 2014). Cotton is highly vulnerable to broad varieties of lepidopteran pests, and a leading one on the Indian subcontinent is Helicoverpa armigera. A milestone in cotton breeding was the development of transgenic varieties and hybrids containing the cry genes of $B t$ encoding insecticidal proteins that provide protection from lepidopteran pests (Amarjeet et al., 2016). After the introduction of $B t$ cotton in India, the cotton production in terms of area has shown a increase from 7.7 million hectares to 12.25 million hectares and cotton fiber production has significantly increased from 13.6 million bales to 39.1 million bales, whereas pesticides usage to control lepidopteran pests has gone down from 5,748 metric tons to 222 metric tons. Various studies have concluded that $B t$ cotton has increased farmer's financial earnings including those of smallholder farmers, reduced pesticide usage and even improved natural biocontrol (Chaudhary and Gaur, 2015).

Monsanto a leading name in the agriculture industry came up with the different varieties of genetically modified cotton crop. These varieties carry different cry genes or its combination. Bollgard $\AA$ is a trademark for the transgenic cotton varieties developed and introduced by Monsanto. Bollgard ${ }^{\circledR}$ cotton is genetically modified to resist lepidopterous insect pests, has had a dramatic effect on cotton production. The main objective behind product concept was clear. Bt bacteria which is found in soil, was well known for producing a effective, specific and safe protein insecticide.

This protein was well characterized, considered safe, and specific to the lepidopterous class of insects. By introducing the Cry gene synthesizing the Cry protein of $B t$ into plants genome, so that these plants would produce their own insecticide. This simple concept promised to reduce insecticide applications, improve insect control, and provide opportunities for aggressive integrated pest management systems while maintaining the inherent safety of this insecticidal protein (Perlak et al., 2001). 


\section{Materials and Methods}

In this study two trials were conducted with total 9 treatments plots of $B t$ cotton plants on the basis of different row patterns that is one row of $n B t$, two row of $n B t$ and no rows of $n B t$ around the plots. Along with introducing different concentration of nitrogen, which is $7 \mathrm{gm} / \mathrm{m} . \mathrm{sq}$., $14 \mathrm{gm} / \mathrm{m} . \mathrm{sq}$. and $21 \mathrm{gm} / \mathrm{m} . \mathrm{sq}$ in each plots (Gangaiah et al., 2013). Field trials of $B t$ cotton BollgardII (KCH14K59) Jadoo variety (commercial name) was done and the upper leaf from the Bt cotton plant is obtained for the ELISA analysis. The sample is collected in a random manner from each plot in duplicate. These samples were collected and analyzed for the quantification of cry1 Ac protein in different time intervals of 30,45 , 60, 90, 120 and 150 days after sowing.

The Quantification of Cry1AC protein was done by Bt-Quant Kit acquired from Central Institute for Cotton Research.

For protein quantification the two punches from each cotton leaf was taken and crushed in a $02 \mathrm{ml}$ eppendorf tube along with $500 \mathrm{ul}$ of extraction buffer. After the crushing of a leaf disc, centrifuged it at 10,000rpm for 5 minutes at room temperature. Mean time 50ul of enzyme conjugate was added in a 96well microtitter plate which is embedded by the specific antibody of cry protein. Add 50ul of centrifuged sample in each well and Keep it for one hour incubation. Later give washing by pipetting out the sample and enzyme conjugate with washing buffer. Once the washing is done add 100ul of substrate in to the wells and wait for 20 minutes, then add $50 u$ of the stop solution to stop the reaction in the wells. The reading was taken at $450 \mathrm{~nm}$.

\section{Results and Discussion}

There were total 9 treatments plots of $B t$ cotton plants from which $\mathrm{T} 1, \mathrm{~T} 2, \mathrm{~T} 3$ were treated with 7,14 and $21 \mathrm{gm} / \mathrm{m} . \mathrm{sq}$. of nitrogen with one row combination of $n B t$ cotton plants while T4,T5,T6 were having two rows combination of $n B t$ cotton plants with same nitrogen treatment as in above mentioned plots. Whereas T7,T8 and T9 were only treatment with different concentration of nitrogen and there was no rows of $n B t$ cotton plants around the plots.

Comparison of means for Cry1 Ac in one rows of $n B t$ crops in BG-II field trials with treatment of different nitrogen content in the soil among respective plots

The mean results of first trial and second trial (Fig.1 and Fig.2) was calculated by using the WASP tool which is available on ICAR Goa website. The plots T1, T2 and T3 which shared one rows of $n B t$ between the plots, shows on the $30^{\text {th }}$ day ELISA analysis for Cry1Ac protein expression, that the highest cry1 Ac expression in the upper leaves of $B t$ cotton plant was in plot T3. Which was treated with $21 \mathrm{gm} / \mathrm{m}$.sq of nitrogen the mean of T3 is $6.023(\mu \mathrm{g} / \mathrm{gm})$ and $6.066(\mu \mathrm{g} / \mathrm{gm})$ in respective trials 90 (Gangaiah et al., 2013).

Least expression was reported in $B t$ cotton plant leaves of plot $\mathrm{T} 1$ which has the mean value of 5.946 $(\mu \mathrm{g} / \mathrm{gm})$ and $5.866(\mu \mathrm{g} / \mathrm{gm})$ and got treated with $7 \mathrm{gm}$. Whereas the expression mean of plot $\mathrm{T} 2$ which was treated with $14 \mathrm{gm} / \mathrm{m}$.sq. of nitrogen is higher than $\mathrm{T} 1 \mathrm{but}$ lower than T3 with the mean value of $6.013(\mu \mathrm{g} / \mathrm{gm})$ and $5.946(\mu \mathrm{g} / \mathrm{gm})$. In the other days of analysis which were $45^{\text {th }}, 60^{\text {th }}, 90^{\text {th }}$, $120^{\text {th }}$ and $150^{\text {th }}$.

The expression of crylAc protein was gradually decreasing in all the above mentioned plots (Kranthi et al., 2005). At the $150^{\text {th }}$ day the mean of plots $\mathrm{T} 1$ is $0.296(\mu \mathrm{g} / \mathrm{gm}) \quad$ and $0.313(\mu \mathrm{g} / \mathrm{gm}), \quad \mathrm{T} 2$ $0.334(\mu \mathrm{g} / \mathrm{gm})$ and 0.352 and T3 $0.384(\mu \mathrm{g} / \mathrm{gm})$ and $0.382(\mu \mathrm{g} / \mathrm{gm})$ (Gangaiah et al., 2013). 
The results show the expression difference by varying nitrogen concentration in the soil, because the plot which was rich in nitrogen concentration gave the highest protein expression level in its plants.

Comparison of means for Cry1Ac in two rows of $\mathrm{nBt}$ crops in BG-II field trials with treatment of different nitrogen composition among respective plots

The expression of cry1Ac for the plots T4, T5 and T6 which were treated with same $7 \mathrm{gm}$, $14 \mathrm{gm}$ and $21 \mathrm{gm}$ of nitrogen per meter square in the plot and having two rows of $n B t$ between the plots shows the prominent results. Plot T4 which was treated with $7 \mathrm{gm} / \mathrm{m}$.sq. of nitrogen showed the minimum expression mean in both the trials $5.816(\mu \mathrm{g} / \mathrm{gm})$ and $6.306(\mu \mathrm{g} / \mathrm{gm})$ when compared to other two plots T5 and T6. Cry1Ac expression in the $B t$ cotton plant leaves is higher in plot T5 $6.382(\mu \mathrm{g} / \mathrm{gm})$ and $6.406(\mu \mathrm{g} / \mathrm{gm})$, while comparing it with plot T4.

Whereas plant leaves of plot T6 showed the significantly high results for expression of Cry1Ac protein with the mean of $6.511(\mu \mathrm{g} / \mathrm{gm})$ and $6.443(\mu \mathrm{g} / \mathrm{gm})$ (Dohare and Tank, 2014) which is higher than other two comparative plots with different nitrogen content in the soil. Here also the expression was decreasing by passing days after sowing and on the analysis of the $150^{\text {th }}$ day after sowing the expression results were minimum but in the similar pattern of expression in different plots. T4 $0.425(\mu \mathrm{g} / \mathrm{gm})$ and $0.433(\mu \mathrm{g} / \mathrm{gm}), \quad \mathrm{T} 5 \quad 0.466(\mu \mathrm{g} / \mathrm{gm})$ and $0.453(\mu \mathrm{g} / \mathrm{gm}), \quad$ T6 $0.473(\mu \mathrm{g} / \mathrm{gm}) \quad$ and 0.477( $\mu \mathrm{g} / \mathrm{gm})$ (Pomgothai et al., 2010). Due to the varying nitrogen concentration in the soil the result was high in the plot which was high in nitrogen concentration compared to other plots.
Comparison of means for Cry1Ac in plots without any rows of $\mathrm{nBt}$ crops in BG-II field trials with treatment of different nitrogen composition among respective plots

This set of treatments which were without any rows of $n B t$ between the plots treated with 7 , 14 and $21 \mathrm{gm} / \mathrm{m}$.sq of nitrogen in the soil. The $30^{\text {th }}$ day analysis of ELISA for analyzing the cry1Ac protein expression in the T7,T8 and T9 plots determines that the protein expression was similarly high in the T9 plot $(21 \mathrm{gm} / \mathrm{m} . \mathrm{sq} \mathrm{N})$ as it was in other set of plots discussed above. Leaves samples derived from the $B t$ cotton plants of T9 plot gave the higher expression mean $5.516(\mu \mathrm{g} / \mathrm{gm})$ and $5.511(\mu \mathrm{g} / \mathrm{gm})$ compared to other two plots $\mathrm{T} 7(7 \mathrm{gm} / \mathrm{m} . \mathrm{sq} . \mathrm{N})$ and $\mathrm{T} 8(14 \mathrm{gm} / \mathrm{m} . \mathrm{sq}$. N). The mean values of $\mathrm{T} 7$ is $5.312(\mu \mathrm{g} / \mathrm{gm})$ and $5.486(\mu \mathrm{g} / \mathrm{gm})$ and $\mathrm{T} 8$ with mean values $5.346(\mu \mathrm{g} / \mathrm{gm})$ and $5.543(\mu \mathrm{g} / \mathrm{gm})$ in both the trials. Mean values of these plots at $150^{\text {th }}$ day analysis shows that the protein expression is comparatively less than other days of analysis. T7 $0.223(\mu \mathrm{g} / \mathrm{gm})$ and $0.243(\mu \mathrm{g} / \mathrm{gm})$, T8 $0.308(\mu \mathrm{g} / \mathrm{gm})$ and $0.267(\mu \mathrm{g} / \mathrm{gm})$, T9 $0.356(\mu \mathrm{g} / \mathrm{gm})$ and $0.333(\mu \mathrm{g} / \mathrm{gm})$ (Srikanth et al., 2018). The comparison shows that the plot which was high in nitrogen content posses high cry1 Ac expression which means that nitrogen concentration do have a impact on the protein expression.

\section{Comparison of means for Cry1Ac expression among all the treated plots}

While comparing the Cry1Ac expression among all the plots as seen in the graphical representation of both the trials (fig:1and2) was highest in the Treatment T6 which was 6.511 and $6.443(\mu \mathrm{g} / \mathrm{gm})$ in respective field trials at 30 days after sowing. This plot was treated with $21 \mathrm{gm} / \mathrm{m} . \mathrm{sq}$. of nitrogen. Which clearly shows a significant difference in expression of cry1 Ac protein while compared 
to other treatments which were having different rows combination of $n B t$ and nitrogen content on the plot. Though the expression of the cry protein was found to be gradually decreasing in 45,60,90, 120 and 150 days after sowing. The lowest reported expression was found on the plot T7 which was not treated with any rows combination of $n B t$ only having least treatment concentration of nitrogen which was $7 \mathrm{gm} / \mathrm{m}$.sq. the expression of cry protein on $30^{\text {th }}$ day after sowing was 5.312 and $5.486(\mu \mathrm{g} / \mathrm{gm})$.
On the $150^{\text {th }}$ day the mean value of the cry1Ac expression of these highest and lowest plots were also showed significant difference. T6 $0.473(\mu \mathrm{g} / \mathrm{gm})$ and $0.477(\mu \mathrm{g} / \mathrm{gm})$ and $\mathrm{T} 7$ with the mean values $0.223(\mu \mathrm{g} / \mathrm{gm})$ and $0.243(\mu \mathrm{g} / \mathrm{gm})$ (Manjunatha et al., 2015). Due to the different rows combination and nitrogen concentration the cry $1 \mathrm{Ac}$ expression was higher in the plot which was having more number of $n B t$ rows and high in nitrogen concentration in its soil.

Fig.1 Cry1Ac expression during first field trial

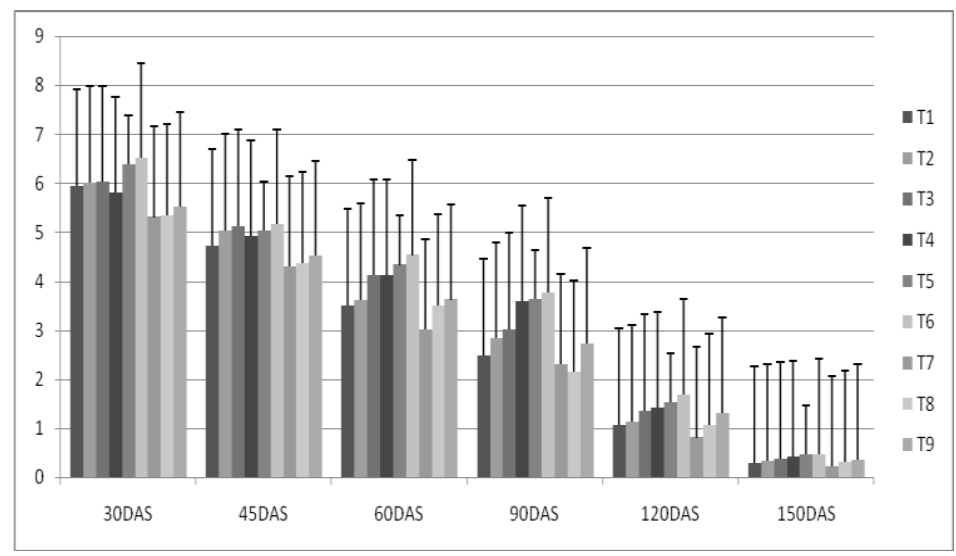

Fig.1 Cry1Ac expression during second field trial

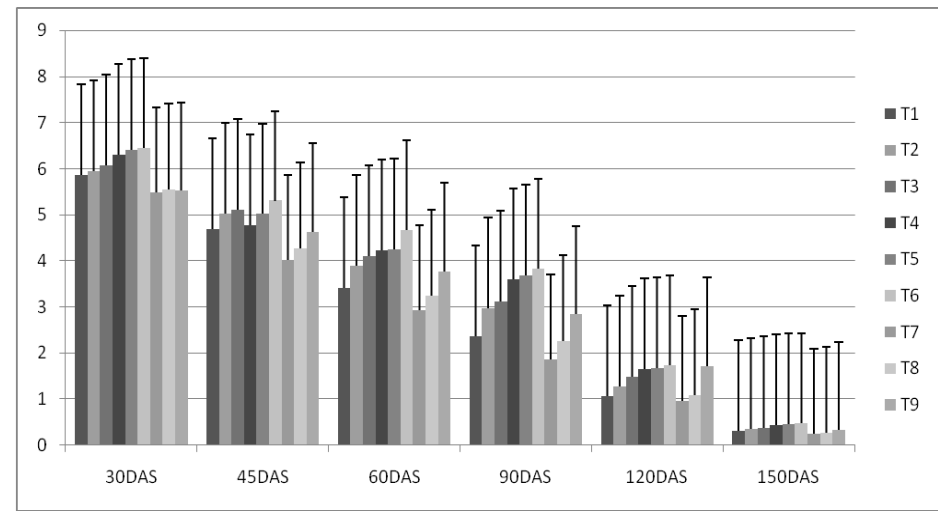

In conclusion, the comparative study among the plots with same row pattern but different nitrogen content for determining the cry $1 \mathrm{Ac}$ expression effect due to these morphological parameters shows that the $B t$ cotton plant in plots having different nitrogen content in there soil poses significant impact on the cry $1 \mathrm{Ac}$ and enhances its expression. During the analysis for the expression of cry 1 Ac protein it was seen that the expression level was high at the initial days after sowing that is $30^{\text {th }}$ day and after that the expression level started 
decreasing gradually in all the treatments which was observed during the respective days interval of analysis. Whereas the results also determines that the different row pattern between the plots which also constitute different percentage of refuge crops along with $B t$ cotton gives a impact on the expression of cry1Ac protein

\section{References}

Subash, S.P., Chand, P. and Balaji, S.J. 2017. Pesticide Use in Indian Agriculture: Trends, Market Structure and Policy Issues ICAR Technical report, December.

Dohare, A. and Tank, S.K. 2014. Identification of Cry1Ac and Cry2Ab Proteins In Transgenic Cotton Seeds Available In Gujrat (India) by ELISA Method. J. Exp. Biol. Agri. Sci. 2: 43-48.

Mushtaq, R., Shakoori, A.R., Luis, J. and JuratFuentes. 2018. Domain III of Cry1Ac is critical to binding and toxicity against soybean Looper (Chrysodeixis includens) but not to velvetbean caterpillar (Anticarsia gemmatalis). Toxins 10: 9598.

James, C. 2014. Global Status of Commercialized Biotech/GM Crops: ISAAA Brief. 49 (ISAAA: Ithaca, NY.).

Singh, A., Kumar, P., Kant, U., Burma, P.K. and Pental, D. 2016. High Expression of Cry1Ac Protein in Cotton (Gossypium hirsutum) by Combining Independent Transgenic Events that Target the Protein to Cytoplasm and Plastids. PLOS ONE, DOI:10.1371/journal.pone.0158603

Choudhary, B., Gaur, K. 2015. Biotech Cotton in India, 2002 to 2014. ISAAA Series of Biotech Crop Profiles. ISAAA: Ithaca, NY

Perlak, F.J., Oppenhuizen, M., Gustafson, K., Voth, R., Sivasupramaniam, S., Heering, D. et al. 2001. Development and commercial use of Bollgard1 cotton in the USA - early promises versus today's reality. Plant J. 27(6): 489-501.

Gangaiah, B., Ahlawat, I. and Babu, M. 2013. Response of Nitrogen Fertilization on $\mathrm{Bt}$ and non Bt cotton (Gossypium hirsutum) Hybrids, SAARC J. Agri., 11(1): 121-132 .

Kranthi, K.R., Naidu, S., Dhawad, C.S., Tatwawadi, A., Mate, K., Patil, E., Bharose, A.A., Behere, G.T., Wadaskar, R.M. and Kranthi, S. 2005. Temporal and intra-plant variability of Cry1 Ac expression in Bt-cotton and its influence on the survival of the cotton bollworm, Helicoverpa armigera (Hübner) (Noctuidae: Lepidoptera). Curr. Sci. 89: 291-298.

Perumalla, P., Devasahayam, M., Singh, R. and Masih, S.A. 2018. Improved Cry 1Ac Expression Levels During Bt Cotton Cultivation. Res. J. Biotechnol. 13: 20-25.

Poongothai, S., Ilavarasan, R. and Karrunakaran, C.M. 2010. Cry 1Ac levels and biochemical variations in Bt cotton as influenced by tissue maturity and senescence. J. Plant Breed. Crop Sci. 2:96-103.

Manjunatha, S.B., Biradar, D.P. and Aladakatti, Y.R. 2015. Effect of Nitrogen Levels and Potassium Nitrogen Ratios (K:N Ratio) on Endotoxin Expression in $B t$ Cotton Biochem. Cell. Arch. 15:469-473.

\section{How to cite this article:}

Peardon, R., M. Devasahayam, A. Maxton and Masih, S.A. 2019. Optimization of Nitrogen Content for Improved Cry1Ac Expression Level in Bt Cotton. Int.J.Curr.Microbiol.App.Sci. 8(05): 851-856. doi: https://doi.org/10.20546/ijcmas.2019.805.100 